Визначено, що найбільш дочільним $i$ економічно вигідним методом дефектоскопї фанери є ударний метод. Для досліджень було використано зразки фанери 3 дефектом та без нъого. Серед акустичних способів найбільи точним вважають ультразвук, але для його реалізацї поверхню фанери треба обробляти спеціальною речовиною, що робить метод неприйнятним для фанерної сировини. Але з огляду на точність методу був проведений кореляційний аналіз з ударним методом. За вихідні параметри ударного методу обрано кількість пульсацій, частоту коливань та коефічієнт гармонійних спотворень сигналу ударного датчика. Встановлено, що ультразвукові дослідження дають майже однакові результати з попередніми дослідами, особливо з коефічієнтом гармонійних спотворень $\left(K_{2}=0,84\right)$. Це дозволяє стверджувати, що обрані параметри дозволяють надійно виявити дефект у фанері. Запропоновані рішення щодо автоматизації процесу дефектоскоniї. Розроблено пристрій контролю якості та автоматизованого селективного сортування фанери, а також багатоканальну автоматизовану систему контролю якості фанери для встановлення на виробничій лінії. Запропоновані системи дозволять здійснювати автоматизовану дефектоскопію фанери, як у вигляді готової продукції, так $i$ на етапі виробнищтва. Інформачія про якість фанери може бути передана як робітникам складу, так і транспортному роботу, а також на виробничу лінію з метою проведення аналізу та виявлення причин виникнення дефекту $i$ корекиії параметрів технологічного процесу. Автоматизація процесу дефектоскопії дозволить підвищити його швидкість і точність. Запропоновано зручний у використанні відносний критерій якості фанери, який дозволяє виключати похибки виміру через нестабільність амплітуд коливань фанери при ударі датчика. Це дає змогу суттево підвищити точність виявлення внутрішніх дефектів при неруйнівному контролі якості

Ключові слова: фанера, дефектоскопія, ударний метод, селективне сортування, неруйнівний контроль, контроль якості

\section{口-}

UDC 674-419.3

DOI: $10.15587 / 1729-4061.2019 .186150$

\title{
DESIGN OF AUTOMATED SOLUTIONS TO DETECT FLAWS IN PLYWOOD
}

O. B a r a nova

$\mathrm{PhD*}$

E-mail: olhabaranovaa@gmail.com

M. Vas yle nko

$\mathrm{PhD}$

Department of Aviation Computer-Integrated Complexes

National Aviation University

Kosmonavta Komarova ave., 1, Kyiv, Ukraine, 03058

E-mail: m.p.vasylenko@nau.edu.ua

K. S he v c he n k o

Doctor of Technical Sciences

Department of Automatization of Experimental Researches National Technical University of Ukraine "Igor Sikorsky Kyiv

Polytechnic Institute"

Peremohy ave., 37, Kyiv, Ukraine, 03056

E-mail: autom1@meta.ua

Y u . T s a p k o

Doctor of Technical Sciences*

V. D. Glukhovsky Scientific Research Institute for

Binders and Materials

Kyiv National University of Construction and Architecture

Povitroflotsky ave., 31, Kyiv, Ukraine, 03037

E-mail: juriyts@ukr.net

R. O I i i n y k

$\mathrm{PhD}$

Department of Meteorology and Climatology

Taras Shevchenko National University of Kyiv

Volodymyrska str., Kyiv, Ukraine, 01033

E-mail: rv_oliynyk@ukr.net

A. Yeroshenko

PhD

Department of Mechanical Engineering and Wood Technology

Chernihiv National University of Technology

Shevchenka str., 95, Chernihiv, Ukraine, 14035

E-mail: yeroshenkoam@gmail.com

*Department of Technology and Design of Wood Products National University of Life and Environmental Sciences of Ukraine

Heroiv Oborony str., 15, Kyiv, Ukraine, 03041
1. Introduction

In recent years, plywood raw materials are gaining popularity as a substitute for wood in construction and furniture articles. Low weight, resistance to temperature changes, good indicators of durability and strength, as well as environmentally friendliness, are the advantages of application of a given material. The development of various kinds of 
plywood raw materials decoration [1,2] also contributes to its wide use. Therefore, it is a relevant task to improve the quality of such raw materials, which is solved through advances in the technology of manufacturing and automation of flaw detection processes.

The most effective results can be achieved only by the technically correct choice and the application of a non-destructive control method. The choice of a method depends on the material and design of the examined material, the characteristics of defects, the surface of the material being controlled. Methods of non-destructive testing, which are based on measuring the frequency of natural oscillations, although are not commonly used, as, for example, ultrasound, but are now increasingly being implemented in production. Acoustic methods may be divided into the method of free and the method of forced oscillations, which in turn are subdivided into local and integrated methods. For non-destructive testing of multilayer structures, the impedance method is also used. Under these methods, bending oscillations of the sound and low (up to $40 \mathrm{kHz}$ ) ultrasonic frequency band are applied. Control is carried out at a one-sided access along a dry surface of the controlled object. Low-frequency methods control different polymeric composite materials and metals. The disadvantage of the impedance method is the "slamming" of the large size of layering (non-adhesion), the impossibility to detect defects if there are no air gaps and a rapid reduction of sensitivity with increasing the density and rigidity of elements from the side of control.

The advantage of the impact method over other low-frequency methods is a possibility to control an article made from materials with small Young modules and high coefficients of elastic oscillations damping. The capability of the impact method to detect defects on large depth makes it possible to control the quality of a semi-finished plywood during production. In addition, technical implementation of the impact method is much simpler.

\section{Literature review and problem statement}

The influence of a plywood layer grain on shear strength and tensile strength was shown in [3], while paper [4] demonstrated the effect of veneer density on shear strength, and work [5] addressed the issue of additive production of plywood. Papers [3-5] showed the influence of the parameters of technological processes on the mechanical characteristics of plywood, but the attention was not paid to detecting internal defects arising in the process of production and quality control of articles. The issues of flaw detection in wood and wood-based articles were tackled in [6-8], in which detection of internal defects involved the method of synchrotron tomography and the behavior of plywood was investigated under the action of impact influences. The method of synchrotron tomography can effectively detect internal defects, but requires the use of complex, costly, and bulky equipment, which makes it difficult to use it outside the specialized laboratories. However, the results from experimental studies into plywood reaction on impact influences make it possible to argue about a possibility of application, for detection of defects, of impact-acoustic method. The shortcomings of the synchrotron tomography method described above were overcome in paper [9], whose authors applied an ultrasound method for determining the bending strength of wood with artificially formed holes. In [10], a similar method was used to detect a stratification defect in composite wood materials.

However, using the ultrasound method requires that the surface of the examined sample should be coated with a special gel, the application of which would lead to an inevitable damage to the plywood. In addition, papers $[9,10]$ did not pay attention to the automation of a non-destructive testing process and its adaptation for use at current production lines.

An option to eliminate the disadvantages of an ultrasound method could be the application of an impact-acoustic method for flaw detection. Such an approach was employed in papers [11, 12], whose authors analyzed a possibility of using an impact-acoustic method for detecting a defect of stratification in a plywood thickness. In addition, they showed the potential of an impact-acoustic method to reveal internal defects in plywood of other types. This allows us to argue that the further research is advisable to focus on the automation of a non-destructive testing process, improving the speed and accuracy of detecting internal defects in composite materials.

\section{The aim and objectives of the study}

The aim of this study is to devise an easy-to-use quality criterion and to automate the flaw detection process with the possibility of its implementation at a production line. This would make it possible to improve the accuracy and speed of flaw detection in plywood, as well as simplify the process of sorting it according to the number and size of internal defects.

To accomplish the aim, the following tasks have been set:

- to investigate the character of change in the amplitude of plywood oscillations under an impact in the absence and presence of a defect in it;

- to determine the dependence of an acoustic signal from the impact sensor on the mechanical oscillations of the examined material;

- to improve the impact method of plywood quality control in order to enhance its accuracy and to design the structure of a device for its implementation.

\section{Materials and research methods in the development of automated installations for flaw detection in plywood in the production process}

\section{1. Examined materials used in the experiment}

Materials for our study were obtained from the production enterprise PAT "Plywood and slabs" (Kyiv, Ukraine). We chose samples of plywood with a thickness of 7,10 , $14,18,22 \mathrm{~mm}$, dimensions from $100 \times 100 \mathrm{~mm}$ to $400 \times 400$ $\mathrm{mm}$. Defects in the samples were both production-related and specially formed at the predefined characteristics. The simulated defects of stratification had an area of $0.0079 \mathrm{~m}^{2}$ to $0.042 \mathrm{~m}^{2}$ and were located in a sheet of plywood at a depth of 0.004 to $0.018 \mathrm{~m}$. In addition to the defects located inside the sheet, we examined the defects located on the edge of the sheet of plywood, which could be observed visually.

Experiments on the distribution of values of sound speed in plywood were carried out in samples the size of $0.3 \times 0.2 \times 0.022 \mathrm{~m}$ weighing $0.799 \mathrm{~kg}$, with an internal defect of $0.0079 \mathrm{~m}^{2}$. The samples were marked with 25 equal plots 
the size of $0.06 \times 0.04 \mathrm{~m}$. Measurements were conducted at the

Table 1

center of these areas.

To study the distribution of levels of output signal from the impact sensor in the defect location area, we used the samples of plywood from PAT "Plywood and slabs" the size of $200 \times 300 \times 22 \mathrm{~mm}$. Defects of stratification were simulated by gluing with a PVA glue two plates of plywood with thicknesses of $18 \mathrm{~mm}$ and $4 \mathrm{~mm}$. A site of defect with an area of $0.0079 \mathrm{~m}^{2}$ was not covered with glue on both plates. The samples were marked with 100 equal plots the size of $20 \times 30 \mathrm{~mm}$ each. Measurements were carried out at the center of these plots.

To find a correlation between the parameters of the output signal from an impact sensor, we conducted experiments on the samples of plywood the size of $0.3 \times 0.2 \times 0.022 \mathrm{~m}$ and $0.4 \times 0.4 \times 0.01 \mathrm{~m}$. The samples were marked with 100 equal plots the size of $0.02 \times 0.03 \mathrm{~m}$ and $0.04 \times 0.04 \mathrm{~m}$. Measurements were carried out at the center of these plots.

\section{2. Procedure for defining the in-} dicators of samples' properties

Experiments to determine the distribution of sound speed in the plywood plane were carried out using the ultrasonic flaw detector UK-10 PMS with the emitter P111-P 33MS and the receiver P111-0,1-P31MS.

Experiments to determine the number of pulsations $n$, the frequency of free oscillations $f$ and a coefficient of harmonic distortions $K r$ were carried out by means of inducing, in a sheet of plywood, the forced oscillations with the help of an impact influence and their registration by the piezoelectric converter CTS-19.

The scheme of measurements on a sample with a defect is shown in Fig. 1.

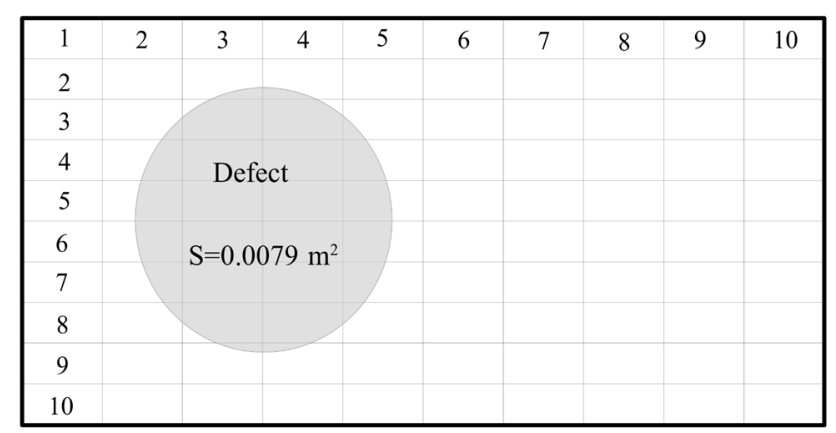

Fig. 1. Scheme of measuring the distribution of levels of output signal from an impact sensor on plywood with a defect

All further experiments were carried out according to the above scheme.

\section{Studying the influence of a defect on the parameters of the output signal from an impact sensor}

Table 1 gives the distribution of values for sound speed $v$ on the plane of plywood with defect.

Distribution of the speed of sound on the plane
of plywood
\begin{tabular}{|c|c|c|c|c|c|}
\hline Length, $\mathrm{m}$ & & \multicolumn{5}{c|}{ Sound speed $v, \mathrm{~m} / \mathrm{s}$} \\
\hline 0.04 & 1,260 & 1,272 & 1,195 & 1,139 & 1,198 \\
\hline 0.08 & 1,206 & 1,195 & 1,223 & 1,164 & 1,250 \\
\hline 0.12 & 1,205 & 501 & 1,204 & 1,223 & 1,165 \\
\hline 0.16 & 1,144 & 911 & 1,238 & 1,250 & 1,261 \\
\hline 0.2 & 1,225 & 1,267 & 1,228 & 1,258 & 1,274 \\
\hline Width, $\mathrm{m}$ & 0.06 & 0.12 & 0.18 & 0.24 & 0.3 \\
\hline
\end{tabular}

Fig. 2 shows a distribution diagram of sound speed on the plywood plane.

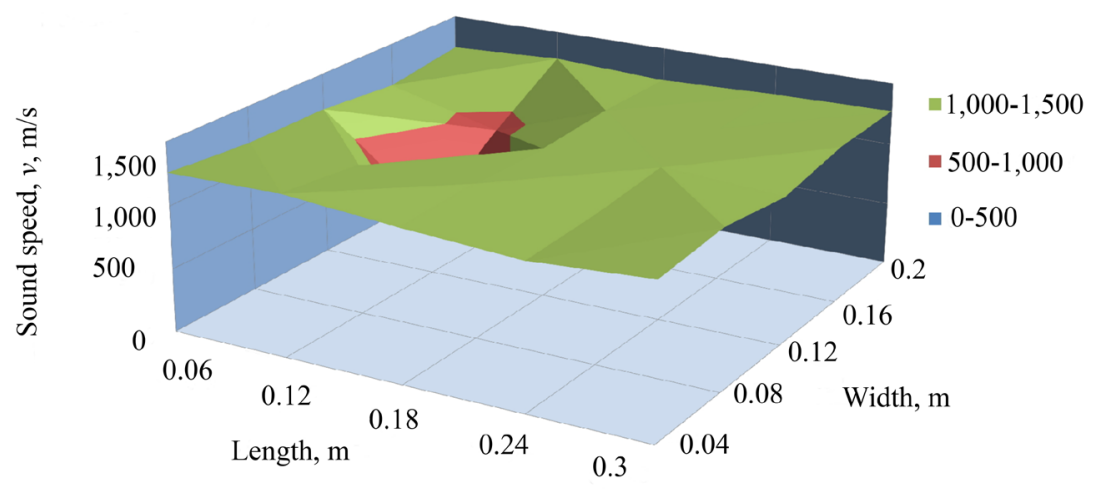

Fig. 2. Distribution of sound speed on the plywood plane

Table 2 gives results from the experiments for a parameter of the output signal from an impact sensor for the number of pulsations $n$ on samples of plywood the size of $0.4 \times 0.4 \times 0.01 \mathrm{~m}$.

Table 2

Distribution of values for the parameter of number of pulsations $n$ on the plywood plane

\begin{tabular}{|c|c|c|c|c|c|c|}
\hline 0.08 & 9.75 & 9 & 8.5 & 9.25 & 9.25 & \multirow{6}{*}{$\begin{array}{c}\text { Mean } \\
\text { value }=9.88 \\
\text { Standard devi- } \\
\text { ation }=1.16 \\
\text { Minimal val- } \\
\text { ue }=7.25 \\
\text { Maximal } \\
\text { value }=11.75\end{array}$} \\
\hline 0.16 & 9.5 & 11.5 & 10 & 11.5 & 10.5 & \\
\hline 0.24 & 7.75 & 8.75 & 9.25 & 11.5 & 9 & \\
\hline 0.32 & 10.25 & 11.75 & 10.5 & 10 & 10.25 & \\
\hline 0.4 & 10.25 & 10.5 & 7.25 & 11.25 & 10 & \\
\hline Width, m & 0.08 & 0.16 & 0.24 & 0.32 & 0.4 & \\
\hline
\end{tabular}

Fig. 3 shows a distribution diagram of the parameter for a signal from an impact sensor of the number of pulsations $n$ on the plywood plane.

The highlighted plot in Table 2 is the site of a defect (mote). In the diagram, red and blue colors indicate a low level of signal that reflects the defective plywood area, green - a defect-free zone.

Table 3 gives results from the experiments for the parameter of an output signal from an impact sensor of free oscillation frequency $f$ on samples of plywood the size of $0.4 \times 0.4 \times 0.01 \mathrm{~m}$. 


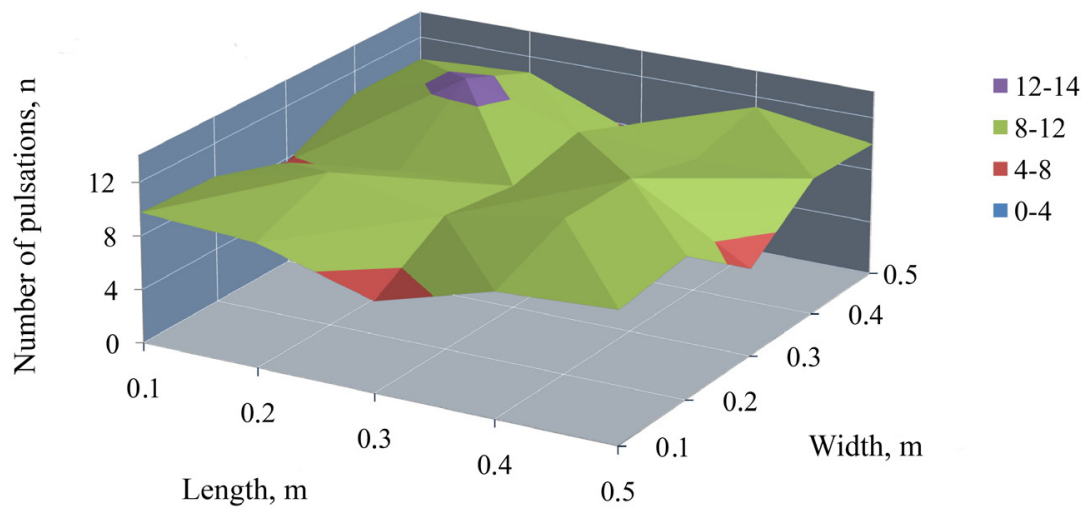

Fig. 3. Distribution of the signal parameter from an impact sensor of the number of pulsations $n$ on the plywood plane

Table 3

Table 4

Distribution of values for the parameter of free oscillation frequency $f$ on the plywood plane

\begin{tabular}{|c|c|c|c|c|c|c|}
\hline Length, & \multicolumn{5}{|c|}{ Data averaged for 4 values } & \multirow[b]{3}{*}{ Mean value $=1.23$} \\
\hline 0.08 & 1.35 & 1.23 & 0.83 & 1.14 & 1.28 & \\
\hline 0.16 & 1.20 & 1.39 & 1.29 & 1.41 & 1.31 & \\
\hline 0.24 & 1.01 & 1.23 & 1.21 & 1.37 & 0.88 & $\begin{array}{c}\text { Standard } \\
\text { deviation }=0.18\end{array}$ \\
\hline 0.32 & 1.23 & 1.53 & 1.35 & 1.16 & 1.25 & $\begin{array}{c}\text { Minimal } \\
\text { value }(\mathrm{kHz})=0.83\end{array}$ \\
\hline 0.4 & 1.22 & 1.32 & 0.85 & 1.41 & 1.26 & $\begin{array}{c}\text { Maximal } \\
\text { value }(\mathrm{kHz})=1.53\end{array}$ \\
\hline $\begin{array}{c}\text { Width, } \\
\mathrm{m}\end{array}$ & 0.08 & 0.16 & 0.24 & 0.32 & 0.4 & \\
\hline
\end{tabular}

Fig. 4 shows a distribution diagram for the parameter of a signal from an impact sensor of free oscillations frequency $f$ on the plywood plane.

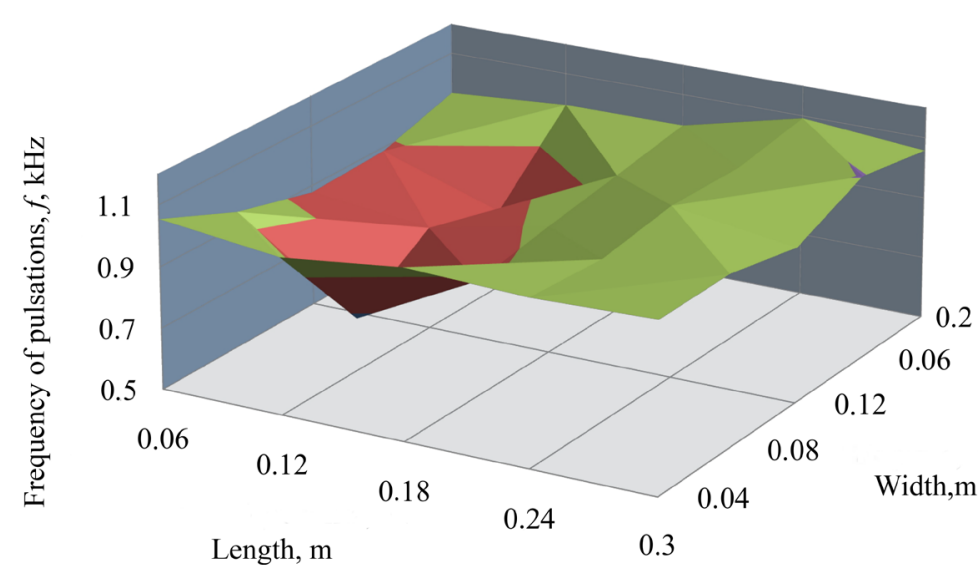

Fig. 4. Distribution of the signal parameter from an impact sensor of free oscillations frequency $f$ on the plywood plane
Distribution of values for the parameter of a harmonic distortion coefficient $\mathrm{Kr}$ on the plywood plane

\begin{tabular}{|c|c|c|c|c|c|c|}
\hline Length, & \multicolumn{5}{|c|}{ Data averaged for 4 values } & \multirow[b]{2}{*}{$\begin{array}{c}\text { Mean } \\
\text { value }=62.33\end{array}$} \\
\hline 0.08 & 58.1 & 57.33 & 44.93 & 62.93 & 66.9 & \\
\hline 0.16 & 69.05 & 84.05 & 72.58 & 57.6 & 72.58 & $\begin{array}{c}\text { Standard } \\
\text { deviation=12.18 }\end{array}$ \\
\hline 0.24 & 42.5 & 56.45 & 49.63 & 47.1 & 57.7 & $\begin{array}{c}\text { Minimal } \\
\text { value }(\mathrm{kHz})=40.80\end{array}$ \\
\hline 0.32 & 59.08 & 73.15 & 54.03 & 80.13 & 69.33 & $\begin{array}{c}\text { Maximal } \\
\text { value }(\mathrm{kHz})=84.05\end{array}$ \\
\hline 0.4 & 57.53 & 77.18 & 40.8 & 79.63 & 67.9 & \\
\hline $\begin{array}{l}\text { Width, } \\
\text { m }\end{array}$ & 0.08 & 0.16 & 0.24 & 0.32 & 0.4 & \\
\hline
\end{tabular}

Fig. 5 shows a distribution diagram of the parameter for a harmonic distortion coefficient $K r$ on the plywood plane.

Table 5 gives the values for coefficients of correlation between the values of output parameters from an impact sensor's -1.1-1.2 signals in earlier experiments, which were $\square$ 0.9-1.1 carried out on samples of plywood the size - 0.7-0.9 of $0.4 \times 0.4 \times 0.01 \mathrm{~m}$ and $0.3 \times 0.2 \times 0.022 \mathrm{~m}$.

0.5-0.7 A significant correlation $\left(K_{n, f}=0.87\right)$ is observed between the number of pulsations $n$ and the frequency of free oscillations $f$ of the output parameter of the impact sensor in experiments involving plywood the size of $0.4 \times 0.4 \times 0.01 \mathrm{~m}$. This is explained by the similarity of these parameters, since the resonance frequency of plywood oscillations has the largest amplitude in the output signal from an impact sensor [11].

In addition, a significant correlation $\left(K_{f K h}=0.83\right)$ was established between the

The results shown in Tables $2-4$ demonstrate that the application of each of the selected output parameters can detect a defect in plywood. The values of the output parameters from an impact sensor's signal at the place of a defect were the smallest in all experiments (values are red in Tables 2-4). frequency of free oscillations $f$ and a harmonic coefficient $K h$ of the output parameter for a signal from an impact sensor in experiments with plywood without defect, the size of $0.3 \times 0.2 \times 0.022 \mathrm{~m}$. In the absence of defects in plywood, oscillations of the latter under the action of an impact pulse on it take the shape close to a pure sinusoid, and the absence 
of additional oscillations makes the parameters of output signals similar. Other correlation dependences were also insignificant.

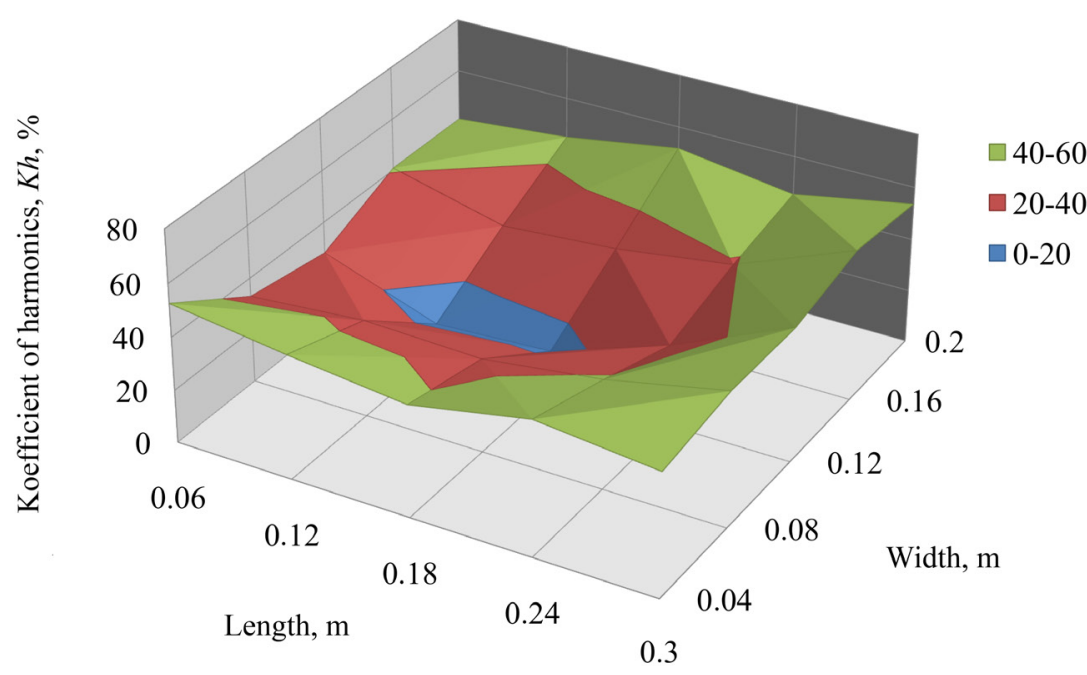

Fig. 5. Distribution of the signal parameter from an impact sensor of harmonic distortion coefficient

Values of correlation coefficients between the values of the initial parameters for the impact sensors' signals

\begin{tabular}{|c|c|c|c|}
\hline \multirow{2}{*}{ Correlation between: } & \multicolumn{3}{|c|}{ Plywood dimensions } \\
\cline { 2 - 4 } & \multicolumn{2}{|c|}{$0.3 \times 0.2 \times 0.022 \mathrm{~m}$} & $0.4 \times 0.4 \times 0.01 \mathrm{~m}$ \\
\cline { 2 - 4 } & $\begin{array}{c}\text { Plywood } \\
\text { without defect }\end{array}$ & $\begin{array}{c}\text { Plywood with defect } \\
\text { (stratification) }\end{array}$ & $\begin{array}{c}\text { Plywood with } \\
\text { defect (bough) }\end{array}$ \\
\hline $\begin{array}{c}\text { number of pulsations } n \text { and } \\
\text { oscillation frequency } f\end{array}$ & -0.36 & 0.27 & 0.87 \\
\hline $\begin{array}{c}\text { number of pulsations } n \text { and a } \\
\text { harmonic distortion coefficient }\end{array}$ & 0.52 & -0.40 & 0.29 \\
\hline $\begin{array}{c}\text { oscillation frequency } f \text { and a har- } \\
\text { monic distortion coefficient } K h\end{array}$ & -0.83 & -0.50 & 0.34 \\
\hline
\end{tabular}

Thus, we can conclude that the selected output parameters for an impact sensor's signals can be used in the quality control of plywood independently of each other.

\section{Automation of the process of plywood quality control}

In order to automate the process of flaw detection in the technological process, we have designed a system of flaw detection and the automated selective sorting of plywood.

In order to automate the process of defective plywood rejection, we have proposed a device to control quality and to automate the selective sorting (Fig. 6). Underlying it is the setting of an automated selective sorting based on the size and number of defects.

The device includes piezo sensor 1 , amplifier 2, information processing unit (spectrum analyzer) 3 , delay line 4, comparator 5, T-Trigger 6 , counter 7 , microprocessor 8 , indicator 9 , generator 10 , impact mechanism 11 , marker device 12 , control transducer 13, ultraviolet lamp 14, photodetector 15, analog-digital transformer 16. A controlled article (position at moment $t_{1}$ ) is marked with number 17 , a defect inside it number 18 . The position of controlled article 17 at moment $t_{2}$ is shown in the diagram by the dotted line.
Table 5

The process of plywood quality control is carried out as follows. Controlled article 17 (a sheet of plywood) is moved at a constant speed $v$ in front of piezo sensor 1 and impact mechanism 11, which is connected to generator 10 and hits the surface of plywood with a frequency of the generator. By using piezo sensor 1 , mechanical oscillations of the controlled article, induced by impact mechanism 11, are converted into electric ones, which are enhanced by amplifier 2, they are processed in information processing unit 3 (one can use, for example, a filter or a spectrum analyzer). Next, the signals are delayed for some time in delay line 4, and, from its output and input, the signals arrive to the inputs of comparator 5 . In the absence of defect 18, signals at the input to the comparator will be the same and there will be no signal at its output. With defect 18 emerges in the article at moment $t_{1}$ during its movement past impact mechanism 10, the current signal from the output of the piezo sensor, and, accordingly, from the output of information processing unit 3 will change (due to differences in the resonance characteristics of the plywood area with a defect compared to plots without a defect) and will be different from the signal at the output of delay line 4 , where it was pre-delayed. Due to the difference in the values of signals at the input of comparator 5 , its output will produce a signal. This signal is fed to the input of T-trigger 6 , from the output of which the signal enables counter 7 , which starts counting pulses from generator 10 . If at the movement of article 17 a lot of plywood with defect 18 continues to lie under vibrator 11, then after a while the signal at the output of delay line 4 would be equal to the current one and there will be no signal at the output of comparator 5 . The output of T-trigger 6 is not changed in this case and counter 7 will continue to count pulses from generator 10 . After a certain time $t=t_{2}-t_{1}$ the plot of plywood with defect 18 at movement of article 17 leaves the zone of impact mechanism 11 the current signal in the input of delay line 4 will change (due to changes in the resonance characteristics of the plywood plot without a defect in comparison with a defective plot) and will be different from the signal at its output. The output of comparator 5 will produce a signal that switches T-trigger 6 , from the output of which a signal banning the counting of pulses from generator 10 by counter 7 will arrive. The digital code from the output of counter 7 will be received by microprocessor 8 , where it will be converted to the length of defect 1 section of the plywood plot with a defect, which is displayed by indicator 9 .

When a digital code starts coming in from the counter microprocessor 8 issues the command to marker device 12 , which begins to apply, to the edge of controlled article 17, a label visible in ultraviolet light, which is located opposite the plot with the defect detected. The label will be applied until counter 7 stops counting. 
Thus, the length of the label will correspond to length 1 of defect 18, and the number of such labels will correspond to the number of defects in controlled article 17.

The automated selective sorting of the labeled plywood will be implemented as follows.

A command from microprocessor 9 enables controlled transmitter 13 to turn on ultraviolet lamp 14. The labels applied on controlled article 17 begin to glow. The radiation from labels is perceived by optical converter 15 through a special light filter and, through analog-to-digital converter 16, it enters the microprocessor 8's input in the form of a digital code, the value of which will be proportional to the size and quantity of defects. Based on the value of the digital code, the microprocessor displays on the digital indicator information about the degree of suitability of the controlled article for subsequent use.
Control over a motion speed of the examined sheet is executed by the microprocessor through managing transducer, which sets the corresponding shaft rotation frequency of electric motor 12 .

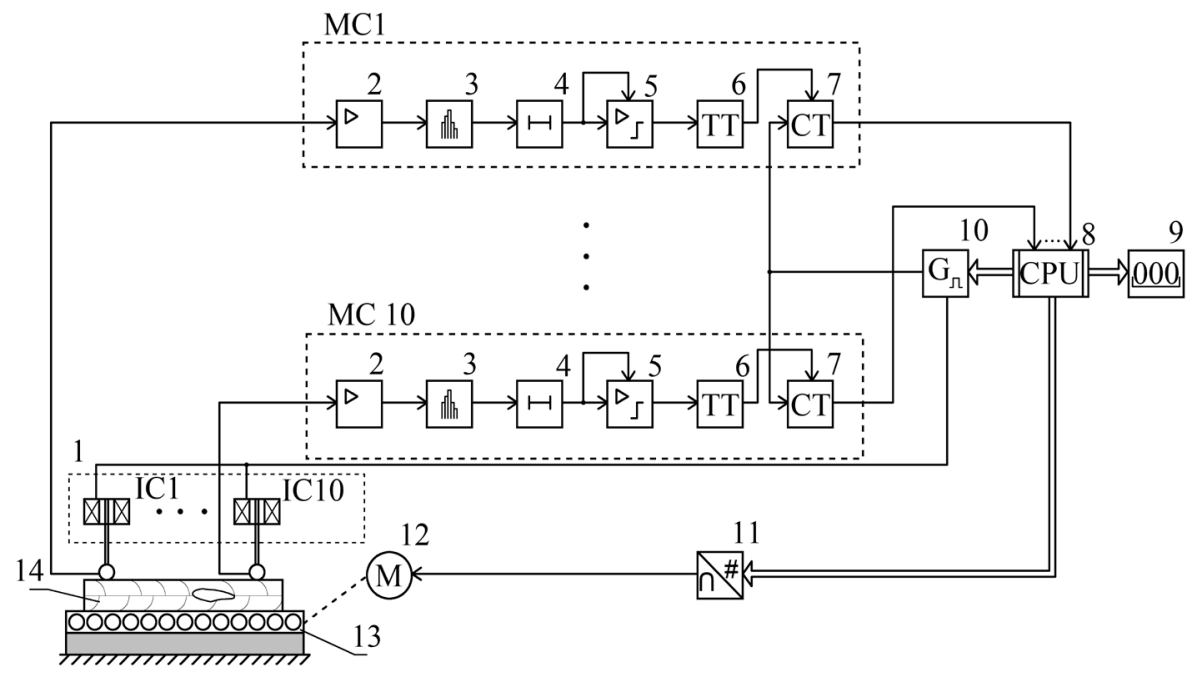

Fig. 7. Multichannel automated system of plywood quality control

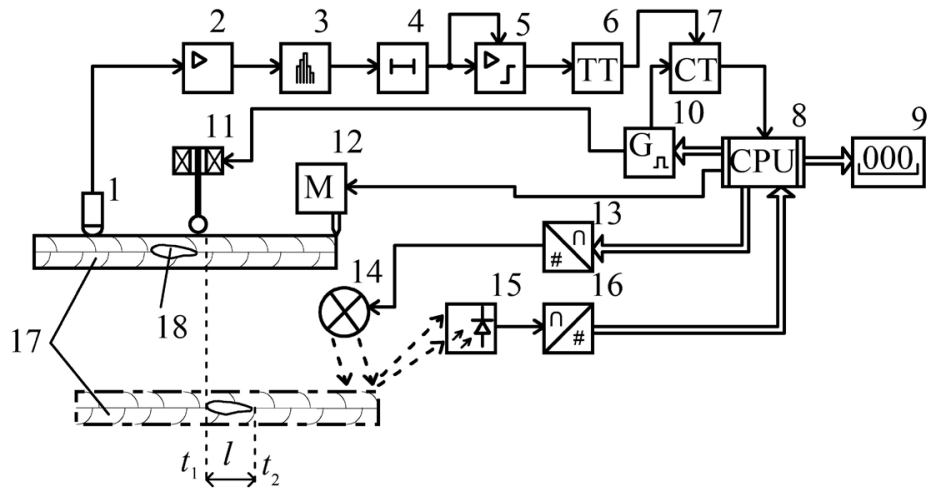

Fig. 6. Device to control quality and to automate the selective sorting of plywood

The disadvantage of a given system is the need to move the impact mechanism and the sensor not only along, but across the width, of the sheet of plywood, which significantly increases the time of flaw detection. To get rid of this drawback one must increase the number of measuring channels for simultaneous coverage of the entire width of the controlled sheet of plywood.

Multichannel system (Fig. 7) is composed of an array of pie zo sensors combined with impact converters (IC1...IC10) 1 and identical measuring channels (MC1... MC10), each of which contains amplifier 2, information processing unit (spectrum analyzer) 3, delay line 4, comparator 5, T-trigger 6, counter 7 , connected to microprocessor 8 , indicator 9 , generator 10, controlling converter 11 , electric motor 12 , automated plywood feeder 13, controlled article 14 .

The process of plywood quality control is similar to a single-channel system, but a greater number of measuring channels allows simultaneous measurements along the entire width of a sample. This makes it possible to reduce the time of observation and increase the speed of the longitudinal movement of the examined sheet of plywood.
The application of 10 identical measuring channels will make it possible to detect flaws in a sheet of plywood along all its entire width will make it possible to simultaneously determine not only the length of a defect but also its position along the width of the sheet depending on which of the 10 available measurement channels detected a defect. Based on information about the size and number of detected defects the system can make a conclusion about the suitability of the examined sheet of plywood for further use.

The proposed systems make it possible to perform the automated detection of flaws in plywood, which significantly increases the speed and accuracy of the flaw detection process especially in comparison with manual methods. Information about the condition of plywood can be transferred both to workers at a warehouse and to a transportation robot, as well as to a production line, in order to analyze and identify the causes of a defect and to adjust the technological process parameters.

\section{Studying the correlation of results from plywood quality control when using the impact acoustic and ultrasound methods}

Our experiments on comparing the output parameters for an impact sensor's signal to results from the ultrasonic quality control of plywood have allowed us to propose a quality criterion. Tables $6-8$ give the results from calculating the main output parameters for an impact sensor's signal, which display information about the presence of a defect in plywood.

The results of correlation coefficients calculation of parameters for the output signal from an impact sensor, given in Table 8 , have made it possible to form a relative numerical criterion of plywood quality. 
Table 6

Results from studying the selection of a plywood quality criterion

\begin{tabular}{|c|c|c|c|c|c|c|c|c|c|c|}
\hline Length, $\mathrm{m}$ & 0 & 0.06 & 0.09 & 0.12 & 0.15 & 0.18 & 0.21 & 0.24 & 0.27 & 0.3 \\
\hline Speed sound $v, \mathrm{~m} / \mathrm{s}$ & \multicolumn{2}{|c|}{1201} & \multicolumn{2}{|c|}{501} & \multicolumn{2}{|c|}{870} & \multicolumn{3}{|c|}{1118} & \multicolumn{2}{|c|}{1187} \\
\hline Number of pulsations, $n$ & 10 & 10 & 5 & 10 & 7 & 12 & 11 & 11 & 14 & 14 \\
\hline Natural frequency amplitude, $A_{1}, \mathrm{mV}$ & 67 & 31.6 & 83.2 & 19.4 & 25.6 & 39.9 & 46.6 & 37.3 & 39.8 & 43.4 \\
\hline Maximal harmonic amplitude, $A_{\text {imax }}, \mathrm{mV}$ & 1.45 & 1.83 & 20.90 & 4.80 & 5.25 & 1.00 & 1.05 & 0.80 & 0.90 & 0.70 \\
\hline Harmonics coefficient, $\mathrm{Kh}$ & 3.9 & 7 & 27.9 & 25.6 & 22.6 & 4.3 & 3.8 & 3.7 & 3.9 & 2.6 \\
\hline Natural frequency, $f, \mathrm{kHz}$ & 3.80 & 5.06 & 1.33 & 3.02 & 3.67 & 3.87 & 4.35 & 3.98 & 4.50 & 4.45 \\
\hline
\end{tabular}

Table 7

Mean values of the initial parameters for an impact sensor

\begin{tabular}{|c|c|c|c|c|c|c|}
\hline Length, $\mathrm{m}$ & 0.06 & 0.12 & 0.18 & 0.24 & 0.3 & Max \\
\hline Speed sound $v, \mathrm{~m} / \mathrm{s}$ & 10.00 & 7.50 & 9.5 & 11 & 14 & 14 \\
\hline Number of pulsations, $n$ & 1201 & 501 & 870 & 1118 & 1187 & 1201 \\
\hline Natural frequency amplitude, $A_{1}, \mathrm{mV}$ & 49.3 & 51.3 & 32.75 & 41.95 & 41.6 & 51.3 \\
\hline Maximal harmonic amplitude, $A_{\text {imax }}, \mathrm{mV}$ & 1.64 & 12.85 & 3.13 & 0.93 & 0.8 & 12.85 \\
\hline Harmonics coefficient, $\mathrm{K} h$ & 5.45 & 26.75 & 13.45 & 3.75 & 3.25 & 26.75 \\
\hline Natural frequency, $f, \mathrm{kHz}$ & 4.43 & 2.18 & 3.77 & 4.17 & 4.48 & 4.48 \\
\hline
\end{tabular}

Normalized values of output signals from an impact sensor

\begin{tabular}{|c|c|c|c|c|c|c|}
\hline$V n=V / V_{\max }$ & 1.00 & 0.42 & 0.72 & 0.93 & 0.99 & $\begin{array}{c}\text { Correlation } \\
\text { coefficient } \\
\text { to } V\end{array}$ \\
\hline$n_{n}=n_{a v} / n_{\max }$ & 0.71 & 0.54 & 0.68 & 0.79 & 1.00 & 0.788 \\
\hline$A_{1 \mathrm{n}}=A_{1} / A_{1 \max }$ & 0.96 & 1.00 & 0.64 & 0.82 & 0.81 & -0.216 \\
\hline$K h_{n}=K h_{a v} / K h_{\max }$ & 0.20 & 1.00 & 0.50 & 0.14 & 0.12 & -0.987 \\
\hline$K_{q}=A_{1}-A_{i \max } / A_{1}$ & 0.97 & 0.75 & 0.90 & 0.98 & 0.98 & 0.981 \\
\hline$f_{1 \mathrm{n}}=f_{1} / f_{1 \max }$ & 0.99 & 0.49 & 0.84 & 0.93 & 1.00 & 0.983 \\
\hline
\end{tabular}

The analysis of initial parameters for an impact sensor has allowed us to establish the dependence of change in the amplitude of natural frequency of plywood oscillations on the presence of harmonic oscillations in it that emerge in the presence of a defect:

$$
\begin{gathered}
K_{q}=\frac{A_{1}-\sum_{i=2}^{n} A_{i}}{A_{1}}, \\
K_{q}=\frac{A_{O}-K_{\mathrm{h}}}{A_{O}} \cdot 100 \%,
\end{gathered}
$$

where $A_{1}$ is the amplitude of natural frequency of a plywood sheet's oscillations, $\mathrm{m} ; A_{i}$ is the amplitude of the $i$-th harmonic oscillation of plywood, $\mathrm{m} ; n$ is the number of controlled harmonic oscillations; $i$ is the number of a harmonic oscillation.

When converting mechanical magnitudes of plywood oscillations into electric ones, the value of a plywood quality criterion is:
Table 8

$$
\begin{gathered}
K_{\mathrm{q}}=\frac{U_{1}-\sum_{i=2}^{n} U_{i}}{U_{1}}, \\
K_{q}=\frac{A_{O}-K_{\mathrm{h}}}{A_{O}} \cdot 100 \%,
\end{gathered}
$$

where $U_{1}$ is the amplitude of natural frequency of a plywood sheet's oscillation, $\mathrm{V} ; U_{i}$ is the amplitude of the $i$-th harmonic oscillation of a plywood sheet, $\mathrm{V} ; i$ is the number of a harmonic oscillation.

Fig. 8 shows dependences of the magnitude of normalized quality criteria on a defect in plywood, which demonstrated high correlation $(r=0,98)$ between plywood quality control by the impact method and the ultrasonic one.

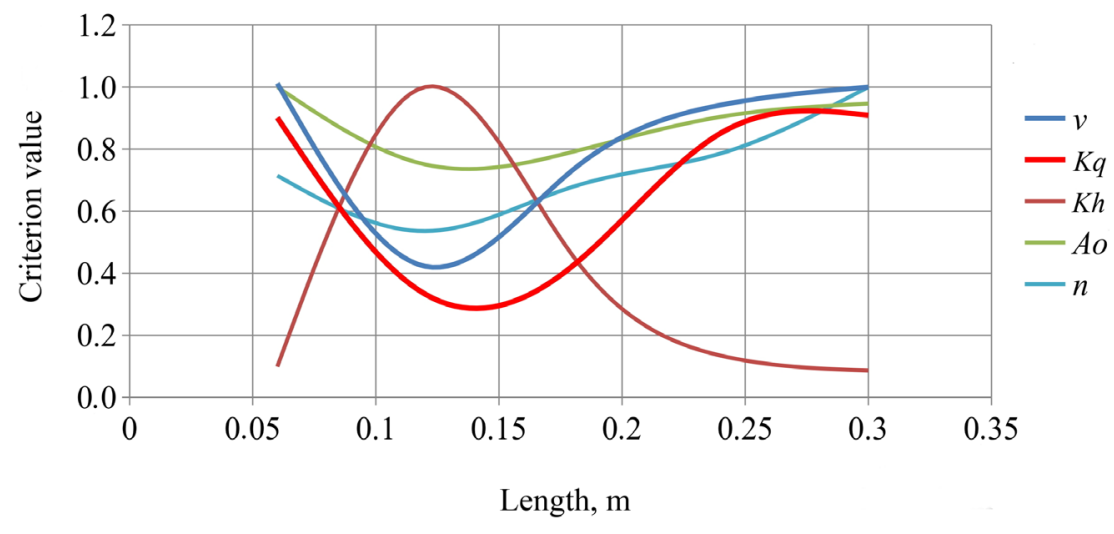

Fig. 8. Dependence of the magnitude of normalized quality criteria on a plywood defect

When calculating the criterion, we have adopted, in this case, a single maximal harmonic as the harmonic oscillation of plywood. When measuring amplitudes of several harmonic oscillations, the accuracy of control improves. 


\section{Discussion of results from calculating the correlation between parameters of the output signal from an impact sensor}

For non-defective plywood, which has a homogeneous structure, the reaction to an impact action is the internal fading oscillations, as shown in paper [11]. The amplitude of such oscillations would be maximal at the time of the impact and would rapidly decrease. However, in the presence of a defect, there would appear additional harmonics, whose amplitude could even exceed the initial. This can be explained by the difference between the elastic properties of plywood at a plot with a defect and at the defect-free part of the examined sample. Therefore, the character of change in the amplitude of a signal can be used to judge on the presence of a defect. However, certain instability of the amplitude can be also caused by the uneven roughness or humidity of the plywood surface, which can cause difficulties in detecting defects with small area.

We have studied, as additional informative parameters, the number of pulsations $n$, the frequency of free oscillations $f$ and a coefficient of harmonic distortions $K h$ of the output signal from an impact-acoustic converter. All three parameters were found to be sensitive to the presence of a defect (Table 2-4, Fig. 2-5) and acquired minimum values in the area of its location. The obtained results correlate well with the ultrasonic method (Table 8). However, the absolute values of these parameters also depend on the condition of the surface of the examined sample [12], which reduces the accuracy of defect detection.

It is possible to avoid this undesirable effect by applying the devised original relative quality criterion (1), (2), which expresses the percentage of harmonic components with respect to the natural oscillation of a plywood sheet. Such oscillations arise in the plywood with a defect and the less of them under an impact action, the higher the quality of the examined sample. The value of the criterion will decrease when approaching a defective plot, and the minimum value would correspond to the exact place of defect location (Fig. 8). The application of a given criterion has allowed us to confidently identify defects with an area from $0.0079 \mathrm{~m}^{2}$.

For the hardware implementation of the proposed criterion, we have designed a system of plywood flaw detection (Fig. 6), based on an impact-acoustic method, which can automatically induce forced oscillations in the examined sample and assess the parameters of the output signal from an impact sensor. It avoids the shortcomings of the ultrasonic flaw detection method $[9,10]$, namely to do without the use of conductive gels, which inevitably damage the plywood surface. However, certain inconveniences might arise from the need to displace the impact sensor over the surface of plywood by hand. In addition, that does not make it possible to detect flaws in the manufacturing process, as it requires stopping a production line.

A multichannel system (Fig. 7) allows the completely automated flaw detection under conditions of a production line, which implies the installation of an array of impact sensors across the width of a sheet of plywood and its automatic movement lengthwise. This eliminates the need for manual displacement of an impact sensor and improves positioning accuracy relative to the previous position.

It would also be advisable to investigate the mutual effect of impact sensors and a signal interference. It is also necessary to define the noise level, which would be created by a multichannel installation.

Our further research may address the improvement of hardware to implement the impact-acoustic method, to control the physical-mechanical properties of plywood and to detect other types of defects, to apply the flaw detection method to other composite materials. This requires the construction of appropriate mathematical models to establish the character of dependence among the parameters of the output signal from an impact sensor.

\section{Conclusions}

1. The result of our study is the established sensitivity of all the parameters of the output signal from an impact sensor, such as the number of pulsations $n$, the frequency of free oscillations $f$, and a coefficient of harmonic distortions $K h$, to the presence of internal defects in the examined material. Each of the specified parameters has a minimum at the place of defect location.

2. Based on the performed correlation analysis, we have formed a plywood quality criterion, which expresses the percentage of harmonic components with respect to the natural oscillation of a plywood sheet. The relative character of the proposed criterion makes it possible to exclude measurement errors caused by the instability of plywood oscillation amplitude, which significantly improves the accuracy of defect detection. The application of the criterion has allowed us to confidently identify defects with an area from $0.0079 \mathrm{~m}^{2}$.

3. A design of the system has been proposed for plywood flaw detection using an impact-acoustic method, which makes it possible to automate the process of non-destructive testing and significantly improve its speed and accuracy. A feature of this system is the possibility of its application directly at production lines. That would make it possible to detect defects in a plywood semi-finished article in the process of its manufacture, thereby significantly accelerating the process of adjusting technological parameters and reducing the output of defective articles.

\section{References}

1. Pinchevska, O., Smirdriakova, M. (2016). Wood particleboard covered with slices made of pine tree branches. Acta Facultatis Xylologiae Zvolen, 58 (1), 67-74.

2. Skliar, D., Smirdriakova, M., Sedliacik, J. (2017). Selected physical and mechanical properties of plywood faced with wood slices. Acta Facultatis Xylologiae Zvolen, 59 (1), 97-105. doi: http://doi.org/10.17423/afx.2017.59.1.09

3. Bal, B. C., Bektaş, İ., Mengeloğlu, F., Karakuş, K., Ökkeş Demir, H. (2015). Some technological properties of poplar plywood panels reinforced with glass fiber fabric. Construction and Building Materials, 101, 952-957. doi: https://doi.org/10.1016/ j.conbuildmat.2015.10.152 
4. Bekhta, P., Salca, E.-A. (2018). Influence of veneer densification on the shear strength and temperature behavior inside the plywood during hot press. Construction and Building Materials, 162, 20-26. doi: https://doi.org/10.1016/j.conbuildmat.2017.11.161

5. Aydin, I., Demirkir, C., Colak, S., Colakoglu, G. (2016). Utilization of bark flours as additive in plywood manufacturing. European Journal of Wood and Wood Products, 75 (1), 63-69. doi: https://doi.org/10.1007/s00107-016-1096-0

6. Zauner, M., Keunecke, D., Mokso, R., Stampanoni, M., Niemz, P. (2012). Synchrotron-based tomographic microscopy (SbTM) of wood: development of a testing device and observation of plastic deformation of uniaxially compressed Norway spruce samples. Holzforschung, 66 (8), 973-979. doi: https://doi.org/10.1515/hf-2011-0192

7. Susainathan, J., Eyma, F., De Luycker, E., Cantarel, A., Castanie, B. (2018). Experimental investigation of impact behavior of woodbased sandwich structures. Composites Part A: Applied Science and Manufacturing, 109, 10-19. doi: https://doi.org/10.1016/ j.compositesa.2018.02.029

8. Aro, M. D., Brashaw, B. K., Donahue, P. K. (2014). Mechanical and Physical Properties of Thermally Modified Plywood and Oriented Strand Board Panels. Forest Products Journal, 64 (7-8), 281-289. doi: https://doi.org/10.13073/fpj-d-14-00037

9. Mori, M., Hasegawa, M., Yoo, J.-C., Kang, S.-G., Matsumura, J. (2016). Nondestructive evaluation of bending strength of wood with artificial holes by employing air-coupled ultrasonics. Construction and Building Materials, 110, 24-31. doi: https:// doi.org/10.1016/j.conbuildmat.2016.02.020

10. Marhenke, T., Neuenschwander, J., Furrer, R., Twiefel, J., Hasener, J., Niemz, P., Sanabria, S. J. (2018). Modeling of delamination detection utilizing air-coupled ultrasound in wood-based composites. NDT \& E International, 99, 1-12. doi: https:// doi.org/10.1016/j.ndteint.2018.05.012

11. Golovach, V. M., Baranova, O. S. (2016). Analiz koreliatsiyi parametriv vykhidnoho syhnalu udarno-akustychnoho ta ultrazvukovoho metodiv defektoskopiyi fanery. Sovremennye stroitel'nye konstruktsii iz metalla i drevesiny, 20, 27-31.

12. Golovach, V. M., Baranova, O. S. (2015). The Analysis of the Influence of Plywood Defect Specifications on the Amount of Output Ripple of Shock Sensor. Naukovyi visnyk NLTU Ukrainy, 25.10, 280-285. 